

ABSTRACT - This paper analyzes the strategies of the Canadian corporation Quebecor, a conglomerate regarded as the prototypical media company and a veteran in the process of gradual media convergence. This case study is based on ethnographic fieldwork conducted between 1999 and 2005, and on a review of the corporation's activities five years later, in 2010 . Synergistically integrating cross-promoting media, strategic partnerships with other media, and structural innovation, Quebecor is the most strongly committed actor in multiplatform production in Quebec - and beyond in English Canada. It has also become an increasingly avid proponent of the concept of the multitasking journalist. The analysis proposed here illustrates not only the transformation of the work of Quebecor employees but also the strategies deployed by a conglomerate to control financial and business opportunities anticipated through media convergence.

Key words: Media convergence. Quebec. Canada. Multitasking journalist. Media economy.

\title{
OS MULTI-SUPORTES A PLENO VAPOR: O caso da empresa canadense Québecor, 1995-2010
}

RESUMO - Este texto propõe uma análise das estratégias do grupo canadense Québecor a partir de uma pesquisa etnográfica, realizada entre 1999 e 2005 , e de uma revisão das atividades do grupo e do estado das relações sociais cinco anos mais tarde, em 2010. O conglomerado representa o protótipo da empresa de comunicação que entrou, desde muito tempo, em um processo progressivo de convergência midiática. Aliando formas de sinergia na promoção cruzada de suportes, parcerias estratégicas com outros veículos e a introdução de inovações estruturais, o Québecor representa, na província canadense do Quebec, o ator que se dedica com mais intensidade à produção multi-plataformas. Nesse ponto, ele promove a figura do jornalista multitarefas, encorajado a multiplicar não apenas sua competência, mas também a produtividade. Contudo, tal dinâmica não cobre apenas as transformações da atividade trabalhistas dos empregados da empresa, mas mostra também as estratégias utilizadas por conglomerado para gerir as possibilidades financeiras e comerciais prometidas pela convergência.

Palavras-chave: Convergência midiática. Quebec. Canadá. Jornalistas multitarefas. Economia da mídia.

\section{LOS MULTISOPORTES A TODO VAPOR: El caso del grupo canadiense Quebecor, 1995-2010}

RESUMEN - Este trabajo analiza las estrategias del grupo canadiense Quebecor, un conglomerado considerado prototipo de empresa de comunicación que entró hace tiempo en un proceso gradual de convergencia de medios. Este estudio de caso se basa en un trabajo de campo etnográfico realizado de 1999 a 2005 y en una revisión de las actividades de la empresa cinco años más tarde, en 2010. Aliando formas de sinergia para una promoción cruzada, alianzas estratégicas con otros medios de comunicación y innovaciones organizativas, Quebecor representa en Quebec - y fuera en El Canadá anglófono- el actor que se dedica con más intensidad a la producción multiplataforma. Además, se muestra un fuerte defensor de la figura del periodista multitarea. El relato que aquí se propone ilumina no solamente la transformación del trabajo de los empleados de la empresa, sino también las estrategias que un conglomerado implementa para controlar las oportunidades financieras y de negocios que promete la convergencia.

Palabras claves: Convergencia mediatica. Quebec. Canadá. Pediodista multitarea. Economía de los medios. 


\section{INTRODUCTION}

Fifteen years after the purchase of his first newspaper, Pierre Péladeau, omnipresent in the Quebec business world, founded the corporation Québecor, Inc., in 1965. Several years later, he launched two tabloid dailies in quick succession, which were both immediately very successful: Le Journal de Montréal and Le Journal de Québec. At this time, he likewise bought a large number of already existing publications. To strengthen his distribution capacity, Péladeau created his own distribution company, Messageries Dynamiques. The 1970s and 1980 s were characterized by the substantial expansion of the group's printing branch and the massive purchase of diverse media platforms. In the nineties, Péladeau bought Télévision Quatre Saisons (TQS), a private Quebec-based francophone station, acquired several publishing houses, succeeded in procuring Corporation Sun Media for Englishspeaking Canada and created a subsidiary, Québecor Nouveaux Médias. The company thus became a sprawling conglomerate and on numerous occasions, prompted public debate on the ills of media concentration (LE CAM, 2009; DEMERS \& LE CAM, 2003) and the increasingly drastic centralization of Quebec's media landscape in the hands of a few businessmen.

In some respects, Québecor appears to be the prototype of a media firm strategically engaged in the gradual process of media convergence. Combining synergy with the cross-promotion of different platforms, strategic partnerships with other media outlets and the integration of structural innovations, the company now promotes the emergence of multifunctional journalism and even possibly the implementation of storytelling convergence (the convergence of journalistic practices and narrative modes in news delivery). In doing this, the Péladeau 'empire,' as it has been dubbed, illustrates well the five forms of convergence identified by Rich Gordon: convergences of ownership, tactics, structures, information collection and storytelling (cited by QUINN, 2004, p. 112$113)$.

This paper focuses on the online activities of the Québecor group, considering these activities a reflection of the pooling together of the conglomerate's diverse activities. The article adopts a two-fold approach in investigating Québecor's long-term strategy. First, it seeks to echo an ethnographic study carried out between 1999 and 2005 concerning Quebec's online media landscape and the professional practices of website employees. 2 The second outlook leads to a recent 
review of the conglomerate's activities and employee relations. 3 Both angles illustrate the fifteen years of different techniques adopted by the conglomerate in its quest to harness the commercial and financial opportunities promised by convergence, made even more evident by the emergence of the Internet.

First, this paper situates Québecor within the context of the Canadian media industry, and more precisely with regards to the production of Francophone journalism. Recalling the conglomerate's early years, this paper focuses on several episodes of its development. Emphasis will then be placed on the company's adaptation to the internet, and on its period of trial and error in this field during the early $2000 \mathrm{~s}$, after the devastating blow of the general downturn in stock prices. The investigation continues almost to the present day, in 2010, as the group is seemingly staking its bets on the implementation of a domestic news agency, QMI (Québecor Media, Inc.), investigating the success of convergence journalism at the heart of its empire (CAUCHON, 2009-a). The agency's central operations, based in Montreal, already act as a hub. QMI also seems destined to play a strategic role in supplying content to mobile phones, tablets and other small-screen devices.

\section{A HISTORIC CONGLOMERATE IN CONSTANT REORGANIZATION}

The Québecor group was born out of the printing and newspaper industries. On the printing side, its successful flagship was, until the turn of the century, Le Journal de Montréal, a New York-style tabloid: sports, sex and blood.4 It was launched in 1965 during a hard labor dispute at La Presse, then "the greatest French-language daily in America." Today, Le Journal de Montréal is still the French-language daily with the largest circulation in Quebec. On lockout for over a year,5 its 253 unionized employees having been fired by the newspaper's management, the daily paper nevertheless continued to appear thanks to various other means. The other area of success has been Québecor's printing companies. At the end of the last century, Québecor was for a time the second-largest printer in the world. At the turn of the century, business took a turn for the worse and the printing division of Québecor World nearly sank the whole group. The branch was forced temporarily to file for bankruptcy protection. Québecor finally sold Québecor World and forced it to abandon the label Québecor. Since this painful divorce at the turn of the century, Québecor has sought to redeploy itself in other media outlets.

Shortly thereafter, Québecor suffered another setback, due to 
the bursting of the dotcom bubble in the early $21^{\text {st }}$ century. Just before the bubble burst, Québecor had initiated a transaction of almost one billion dollars to purchase a cable company: Vidéotron, the secondlargest Canadian cable company. During this same short time frame, Québecor was not the only Canadian media group to engage in sudden and enormous growth operations, thanks to abundant floating capital on the market (DEMERS, 2003; 2000). For example, Bell Canada, originally active in the telephony sector, acquired CTV (the number one private television station in English-speaking Canada) and the Globe and Mail, a national daily. The conglomerate also nose-dived soon after its expansion and had to divest itself of some of its acquisitions. Spectacular growth was likewise experienced by CanWest-Global, who emerged from the world of television to acquire some 200 publications for sale by Conrad Black of the Hollinger group. Soon after, CanWest began experiencing financial problems and was forced to file for bankruptcy and sell its daily newspapers.

Severed from its printing division and weakened financially, Québecor began its recovery by refocusing its activities on two elements at the heart of Vidéotron, which also had the effect of relegating to the back-burner its daily newspapers, hitherto regarded as the driving force of its media empire (FORTIN, 2007). The first axis of its recovery made the cable distribution network evermore central to its strategy. In addition to a network dedicated to the transmission of television shows, Vidéotron added internet and telephony services. The second strategic pillar of its recovery has been the television channel TVA - far and away the most popular Francophone channel, surpassing both the state channel Radio-Canada and the other general channel V (formerly TQS). The latter now occupies a rather insignificant portion of the market. (To obtain the permission from the Federal Government Regulatory Office (the CRTC) to include TVA in its purchase of Vidéotron, Québecor had to divest itself of TQS).

Despite all of these troubles, today Québecor is at the forefront of convergence and multi-platform production in the French-speaking part of Canada, due to the public's image of its CEO and various characteristics of the company itself. Pierre-Karl Péladeau, heir to the founding father, is known as a "media baron" and nicknamed PKP. For him, media and journalism are business matters like any other. In 2003, in a dramatic and controversial way, Pierre-Karl Péladeau became a standard-bearer for convergence (YAKABUSHI, 2003).

The second reason for Québecor's presence in the spotlight 
concerns the components of its conglomerate. Currently, in the media landscape of French-speaking Canada, it is the only group capable of developing convergent multi-platform content (TV, newspapers, weeklies, magazines, web, mobile) and of targeting both of Canada's linguistic markets, especially with Sun Media, Osprey and Canoe.

\section{QUÉBECOR SPINS ITS WEB THROUGHOUT THE COMMUNICATIONS SECTOR}

Québecor began to structure its online information production around 1997. At this time, it also acquired the news site Canoe (Canadian Online Explorer), based in Toronto, and created its Quebec equivalent, Canoë. Through this "French window," it was then possible to access the websites for Le Journal de Montréal and Le Journal de Québec (INFO PRESSE, 1999, p. 32). Québecor also became interested in urban websites and city guides, and created eight of them across Canada, notably in Montreal (IciMontréal) and in Quebec (IciQuébec). These sites offered entertaining and relevant cultural information. Original content was still rare before 2000. Content other than current news was emphasized, in particular personal ads, games, services, etc.

Québecor was obviously not alone on the market. The trend towards cross-media ownership6 and the broader phenomenon of concentrated corporate ownership began to restructure the online media landscape during the first half of the 2000s. In 2000, four major portals originating from commercial companies burst onto the Quebecois web: Branchez-vous!, Canoë, Sympatico-Lycos and InfiniT.com. These websites sought to provide different types of information, services and entertainment. Each portal was supposed to become a general gateway allowing users to orient themselves, while the conglomerate owning the site could unify all its different services in one place, thus keeping the user within the boundaries of its site.

In the fall of 2000, Québecor purchased Vidéotron and the television station TVA, a transaction that allowed it to become an internet service provider. The conglomerate sought to become the biggest internet player in Quebec by combining the content at its disposal with "the Vidéotron 'outlet,' and the internet as a window" (MARSAN, 2001). Québecor tried to make inroads into Europe, creating two Canoë sites abroad, one in Paris (with some 25 employees) and another in Madrid. The experiment, carried out by two national writing teams who expected the expansion of their activities in "Germany, Chile and all other Latin 
American countries" (TRUDEL, 2000) would not, however, last very long. The French site was forced to close down in 2001.

Layoffs at Netgraphe 7 were cyclical. In 2002, 67 employees lost their jobs in Montreal and Toronto. During restructuring, the InfiniT portal was finally merged with Canoë and a clearer orientation was adopted with regard to the internet distribution of content produced by the other Québecor media outlets (at that time, TVA, Le Journal de Montréal and the Publicor magazines). And indeed, in 2004, Canoë offered on its website the content of all of Quebecor's media outlets, including sites dedicated to reality TV programs broadcast by the conglomerate's TV channels.

Québecor's online activities, structured since 2001 under the umbrella of Québecor Media Inc., included in 2004 the Canoë Network, Webfin8, Jobboom9, RéseauContact 10, La toile du Québec1 1, the TVA Canoë, InfiniT12, the LCN Canoë, the site of Star Académie 13, the site Occupation Double 14 and Canoë Money (GIRARD, 2004). In 2007, through successive purchases, Québecor gradually managed to create a large network of online classifieds by bringing together all of its online and offline publications, under the umbrella of the site vitevitevite.ca.

Throughout all of English-speaking Canada, compared to the giants Bell and Rogers, Québecor remains a player of average importance. On the other hand, in French-speaking Canada, it is the number one player on the media scene.

\section{ZOOMING IN ON THE WEB: NETGRAPHE-CANOË IN 2002}

In 2002, an ethnographic observation of the Netgraphe-Canoë newsroom and interviews conducted with journalists (LE CAM, 2005) allowed for the identification of the main challenges faced by media companies, transitioning from off-line activities, with regard to their entry into online journalism. This study reflected the comprehensive strategies that Québecor sought to implement, while highlighting the difficulties of everyday implementation of the ideas of synergy and "global media."

\section{STRUCTURING WEBSITE ACTIVITIES}

In December 2002, the content of the Netgraphe-Canoe website was produced at two separate locations: the first, produced on-site at TVA, was the online edition of the television news 15 and the second, produced on-site at Vidéotron, welcomed journalists in charge 
of uploading news to the general portal, Сanoë $\square$ and to the different websites belonging to Québecor. At TVA-LCN17, the online newsroom was on the same floor as the television newsroom. It was located in a corner of the room and included three to four computer stations. This small office was only occupied by the salaried journalists and the site coordinator. On the other hand, Netgraphe-Canoë occupied a whole floor at Vidéotron in Montreal. The newsroom was divided by movable walls and included on one side, the journalists of the Canoë website, most notably its new sections: cars, travel, culture, etc., and on the other side, employees of La Toile du Québec, Webfin, Canoë digital and the editor's office, whose official title was "director of content." On that floor, there were also computer specialists, advertisers and marketers.

Autonomy is a recurring word for journalists, who often fear that their work will be confused with that of other company employees. However, intra-conglomerate relations seem extremely tight in the Québecor empire. Canoë's homepage provides access to some newspaper content, including from Le Journal de Montréal, and to all of the content broadcast by TVA-LCN. It also allows users to buy books or CDs from Archambault and find singles on RéseauContact. Canoë employees can copy and republish articles from Le Journal de Montréal. Republication is systematic when the articles deal with events sponsored by Québecor (the "Mannequins d'un jour" [Models for a Day] contest, for example).

Relations between the TVA-LCN and Canoë teams were relatively acrimonious at the time of observation. For example, the TVA website journalists had lost the right to delete and modify their own texts directly on the site; these changes were carried out by Canoë employees. This was perceived as a loss of autonomy, especially when compared to TVALCN's former independence. Canoë seemed to centralize the promotional activities of the whole conglomerate. This strategy seems reciprocal, as many invitations to access the site are issued to the public by Québecor's different subsidiaries, not only in news programs, but also in all types of shows.

The titles of the website managers differ from one media outlet to another. They are called "web activities coordinators" at TVA-LCN for instance, or "directors of content" at Canoë. At Netgraphe-Canoë. In the fall of 2002, fourteen people were working on content delivery. One person was assigned to the "News" section, three to the "Showbiz," "Art de vivre" and "Maison Passion" sections respectively, one employee to the "Travel" section and one to "Bonjour Québec," one person to "Autonet," two employees to Webfin and one individual to Canoë digital. Finally, 
five individuals worked in tandem on La Toile de Québec. The average age of the employees was around thirty. The reporter assigned to the news section was a former TVA employee, hired by Canoë only three months earlier. The journalist specializing in culture and "showbiz" had been there for a year and a half. The two journalists at Webfin, one of whom had a background in translation and writing, had started three months earlier. The one employee assigned to Canoe digital was the site manager and he defined himself as the "webmaster, editor and salesperson" of the site (R-65, 18 Canoë, 2002). Previously a freelancer, he was hired in September 2002, a few months after the launch of the website. At La Toile du Quebec, the respondent, in charge of the directory and tree structure, had previously trained as a librarian.

The TVA-LCN site is updated by the equivalent of two and a half employees and the help of the web activities coordinator. Until July 2002, the people working on this site were supernumery personnel. At that time, they obtained contract positions. Two of the employees work two days a week each. The third position was, at the time of observation, still vacant. (R-23, Tva.ca, 2002).

At Canoë, each employee is assigned to one section of the site. They may, however, change sections throughout the day, depending on the arrival and departure of journalists. Sometimes, journalists have an assigned sector, but for many it changes according to needs, replacements and availability. Production hours seem relatively personalized. Thus, at Canoë, work officially begins around 7am but the director of content updates the site around 4 or $5 \mathrm{am}$, from her home. At TVA, the news is covered by a permanent reporter from $7 \mathrm{am}$ to $2 \mathrm{pm}$ and from $5 \mathrm{pm}$ to $8 \mathrm{pm}$ during the week. Between $2 \mathrm{pm}$ and $5 \mathrm{pm}$, breaking news is uploaded by the site coordinator, or at times managed by Canoë. Content producers all use a support tool for automated layout. These "homemade" software programs have often been designed in collaboration with computer specialists and newsroom representatives. At TVA-LCN, the main software program was christened "la Sentinelle LCN"; it is also used at Canoë and Webfin.

The work of the manager, coordinator or director of content is varied and multi-functional. They have to monitor journalists' assignments by sector and check the speed of posting, layout problems, news wires, television news and the writing of the news published online. They must direct the site's orientation, make connections with advertising, manage technical problems, etc. The director's presence is daily and constant. Their comments to the staff refer first and foremost to the layout and 
speed of posting. They may interact with their reporters at any time; even when absent, they regularly make telephone calls. Nonetheless, online journalists have more freedom in terms of decision-making and taking initiative, provided they remain economically viable. The head coordinator is heavily involved in the site's profitability, in running ads and creating new services on the site. This involvement transfers onto the site's journalists. The site can close at any time, so most of the journalists interviewed were very involved in profitability and constantly seeking improvement. They regularly felt the threat of declining budget allocations, of major hierarchical or organizational changes, or even the site's closure.

\section{ACTIVITIES OF ONLINE JOURNALISTS}

The observation of online journalists has highlighted some specific routines related to the continuous and apparently instantaneous production of information; it also underlines certain writing techniques, the use of hyperlinks and the undertaking of tasks sometimes seemingly remote from the practices of traditional journalists. The main activity of online journalists is publishing news on websites as quickly as possible and most importantly, providing content for their pages as often as possible. In the winter of 2003, one Webfin journalist said he had to write thirty texts per day, or an average of one text every half hour, and two financial columns each week (R-41, Webfin, 2002). At TVA, before their merger with Canoë, the journalists produced between 10 and 12 new stories daily; at the end of 2002, they had to write at least thirty (R23, Tva.ca, 2002).

The news published on the sites is recorded down to the hour or even minute. It is paramount that the news appears to be fresh. The look of the page is often what matters most. For journalists working on the site, this means that they must constantly monitor dispatches from news agencies, updating their site as new information arrives. This constant race determines the layout and hierarchy of information on the site. The latest news stories appear at the top of the page. They then scroll down the main page, although a news story may sometimes return as the page header if the event experiences important repercussions or continued consequences. The links are mainly used to point to content or other sites within the company. Most links refer to similar content, to another subsidiary (for example, Canoë referring to Claire Lamarche's show on 
TVA) or a service (for instance, on Webfin, hypertext links lead to various business fact-sheets). The main objective here is to circumscribe the informational map, in order to keep the user within the organization's virtual space.

The work of an online journalist is not strictly confined to the field of journalism as it is generally understood. They also participate in site updating and in the various activities undertaken to make the site more attractive and "interactive." For example, journalists for the TVA site write the "TVA question of the day," displayed on Canoë's homepage. Forums have also been established for each section. According to their area of assignment, each journalist is then responsible for editing the comments, that is to say, for reading them, verifying if any statements are defamatory, and then posting them online. Early during one observation day, the journalist in charge of the news sector at Canoë had 113 posts to process.

Various functions are required by online journalists, which they must combine on a daily basis. Thus, during one observation day, the head journalist for Canoë's news section was responsible for drafting a newsletter to subscribers, summarizing the past week's news. Another journalist wrote fact sheets on upcoming film releases, gathering his information from other web pages.

Journalists in online newsrooms are often responsible for participating in site performance. They are encouraged to be creative and anticipate foreseeable events. During one editorial conference at Canoë, the Christmas period and the video games industry were jointly addressed so that journalists could create special files (gift ideas, Christmas cards, greeting cards), or animations (presentation of the internet's highestrated games), etc.

\section{REAL JOURNALISM OR JUST TRANSMITTING INFORMATION?}

During our observation, no external fact-checking processes such as phone calls or in-person meetings were noted. Some outside calls were received from companies who wished to publish their press releases, especially on specialized sites such as Webfin.

The plausible nature of information aids in its verification but above all it is confirmed by being repeated throughout other media outlets, including online competitors. Information published in a news wire will be put online very quickly, especially if the story is urgent. The credibility of the story is determined by the fact that AFP and Reuters, 
for example, have published the same story at the same time, or that a competitor has posted a short write-up of the event.

Information searches on the web are relatively commonplace. The use of Google's search engine is quite common, allowing the user to search for specific information and in some cases, for the sites that may be mentioned at the end of the articles. Sometimes, it is used as a dictionary, or to check the spelling of a name or word.

Internet browsing mainly focuses on accessing the web sites of traditional media outlets, national or foreign. When it is a slow news day, especially for specialized sections such as showbiz at Canoë for example, the journalist may scan yahoo.ca, CPNews, the stories on yahoo.fr under the headings Culture and People, actustar.com, people.com, The I Internet Movies Database, etc. Finally, the Eurêka database allows journalists to have access to the articles of most daily papers, including the current day's articles. This archive database allows them to verify certain information or to trace the story of an event. These processes of selection, rewriting and layout are part of the daily routine of an online journalist. Reporting and writing exclusive content are very rare.

At Canoë, our observation took place in 2002 during preparations for the TVA show Star Académie. For several days in November, Canoë journalists took turns, in pairs, to cover on location the candidates' auditions in Montreal. The show's website was launched by Netgraphe, and Canoë journalists inherited responsibility for audio-visual and narrative content. Canoë employees became the journalists of the official Star Académie website. When the show began to tour throughout the country, Canoë journalists had collected enough material to put content online for a month.

At Canoë, reporting on location like this is a rather infrequent event and thus often causes a stir in the newsroom. Even basic reporting is rare. All the journalists interviewed highlighted a lack of time and resources to do on location reporting or even to make phone calls. But at the same time, in a number of ways, these journalists have considerable flexibility and autonomy. Thus, a journalist for Webfin decided to do work in tandem with all the companies listed in the Quebec Stock Exchange: she started to contact them and establish her own sources so that they could send her their press releases directly.

The trend in "passive" journalism, especially with regards to online media, is above all explained by the fact that the online site of a traditional media outlet is often considered to be a simple extension of conventional platforms. Off-line newsrooms already have their production 
routines and dedicated personnel for field reporting, Therefore, sending online journalists as well is seen as an unnecessary double expense.

The circumstances under which the Canoë journalists worked during the period observed strongly resembled the calm after the storm. After having laid off the majority of its online employees, NetgrapheCanoë maintained a handful of positions and hired new editors. These new employees are aware of the situation in which their predecessors had to evolve and, after the latest wave of layoffs, were encouraged to "just" do their job. Likewise, they are also aware of the economic constraints of online journalism and are encouraged by their company to reduce costs. This explains why they do not engage in real reporting and are primarily used to aggregate content from different sources. In this sense, they act like the "good employees" of the 1980s economic climate, as described by Demers (1989), who must take up their company's cause and actively participate in its development.

\section{THE MULTI-PLATFORM APPROACH VALIDATED: CANOË SPEARHEADS THE MOVE TOWARDS CONVERGENCE}

The 2010 publication of a second overall investigation of the Québecor group's activity in online journalism could only be completed with recourse to secondary sources, more specifically information gleaned from various publications, including Le Devoir and the trade magazine Le 30, published by the Fédération Professionnelle des Journalistes du Québec (FPJQ), 19 and through telephone conversations with internal employees. The context of a pitched battle between Québecor and its employees at Le Journal de Montréal for over a year,20 after a very serious conflict lasting 16 months with Le Journal de Québec (April 22, 2007-July 2, 2008) made it too controversial to repeat the ethnographic observation in situ and rendered access to key players and locations very difficult. Yet, an ethnographic examination of the situation conducted thanks to in-depth interviews and longer observation periods would have helped untangle and identify the guiding principles, trajectories and entrepreneurial strategies of the second part of the decade.

It is nevertheless obvious that Canoë has continued to spearhead the convergence of content and professional practices and could lead to this practice being adopted throughout Québecor Media. Until very recently, when Le Journal de Québec and Le Journal de Montréal reappeared with their own individual sites which were accessible by Canoë, the portal had developed its own information service by feeding it 
with the contents of the two dailies and the output of several other media outlets. It even organized its own, small production unit composed of 5 mojos (mobile, autonomous and multi-tasking journalists), which was estimated to grow to 7 in April 2010 (BELLEROSE, 2007). These mobile journalists must produce videos along with radio segments and written stories from a mobile workstation and light equipment (DEMERS, 2007). They work under a "supervisor of video-reporters from Canoë." A space entitled Canoe.tv, online since at least October 2008, allows for the delivery of multimedia pieces produced by the seven mojos, since renamed "video-reporters." These practices seem relatively well appreciated, as they justified the dispatching by Canoë-tv of a videojournalist during the days following the earthquake in Haiti. A special section was even created for him on the homepage, called: "Simon-Pierre in Haiti."

In 2008, the fifteen Canoë journalists produced about $25 \%$ of original content for the site, while the remaining $75 \%$ came mainly from content produced by other media outlets (PROULX, 2008). However, these journalists are still at the heart of tensions between traditional media journalists and the conglomerate's management. Thus, since 2007, during negotiations for collective agreements at Le Journal de Québec and Le Journal de Montréal, one of the stumbling blocks has been the issue of multi-platform production. At Le Journal de Québec, the union demanded strong supervision of the practice, asking in particular whether the work of the daily newspaper's journalists could end up on the Canoë website, without the reverse being possible (DAUDENS, 2008). In the end, however, the lockout forced the union to retreat significantly with regard to the multi-platform question (PORTER, 2008) and it agreed to provide Canoë with content without receiving additional compensation (PELCHAT, 2008). However, the in-house journalists succeeded in retaining their exclusive right to cover the Quebec City region. The content produced by Le Journal de Québec journalists and photographers could be found on Canoë, but not the other way around, at least as far as local information was concerned. Shortly thereafter, Le Journal de Montréal faced the same demands; a lockout has been underway since January $24^{\text {th }}, 2009$ (BAILLARGEON, 2010).21

Journalists are confronted with Québecor's global vision: broadcasting the production of all its journalists across all of its media platforms. At Québecor's general shareholders' meeting in May 2009, Pierre-Karl Péladeau stated this clearly: "The idea is simple: we can no longer afford to do the same thing 25 times in 25 different newsrooms, 
whether it's preparing sports statistics, covering international events, reporting on entertainment news, or establishing TV schedules..." Mr. Péladeau added that several journalists working for the giant "have already learned how to wield a camera, a microphone, a BlackBerry, how to edit videos. They have accepted the fact that the profession has changed irreversibly" (SHIELDS, 2009).

On their advocacy website (which also provides information to learn about online journalism22) ruefrontenac.com, the locked-out journalists from Journal de Montréal went further and suggested that Archambault's online site (the branch of the FNAC owned by Québecor), zik.ca, should be authorized to reuse, for free, content produced by journalists, but that the arrangement should be reciprocal: zik.ca employees should see their critiques or endorsements appear across various media platforms. 23

This synergy of content across many different media assets is what Pierre-Karl Péladeau has himself termed "convergence" and adopted as his strategy. This convergence first took the form of promotional support for TVA's reality shows via the group's other media platforms. Convergence also used the Canoë portal as a leveraging tool. Today, it continues to forge ahead with a new strategy, making inroads in the field of proper journalism: an internal news agency, whose prototype was tested under the name "Nomade" during the lockout of the Journal of Québec's 252 employees.24 Nomade disappeared during the summer of 2008 once the dispute was settled.

Three days after the start of the lockout at Le Journal de Montréal, decreed on January $24^{\text {th }}, 2009$, another news agency appeared in the pages of the daily newspaper, which continued to be published by its senior executives. According to Québecor's spokesman, it was a "content-sharing portal" created at some point during the fall of 2008 (CAUCHON, 2009-b). This agency is called Québecor Media Inc. (QMI) and its head office is located in Montreal (BLAIS, 2009). The circumstances surrounding the creation of this agency make it more difficult to ascertain Quebecor's long-term intentions, since Nomade and QMI were also used as potential weapons during the lockouts.

What is certain is that, in July of 2010, Québecor withdrew from the cooperative news agency La Presse Canadienne (PC). La Presse Canadienne was founded in 1917 to ensure the exchange of local and regional news across Canada. A few years before Péladeau, Conrad Black had announced his intention of withdrawing his subsidiary Southam from the agency. Ultimately, it was CanWest-Global, the heir to his empire, that 
first took this leap in July 2007. At the beginning of the decade, the Gesca group also tried to reduce its use of the agency, imposing the writing of its flagship daily La Presse (Montreal) on its regional newspapers. Finally, at the end of 2010, after the confirmation of Québecor's withdrawal, $L a$ Presse participated with The Toronto Star and The Globe and Mail in an operation to change the structure of the news agency, from a cooperative to a private company (of which it is today a co-owner).25 QMI was also presented as the implementation of a pre-existing structure based on information sharing between the different media outlets owned by Québecor. Employees are now news coordinators, not reporters.

Originally located within Québecor's headquarters, QMI ultimately moved to the Canoë office. One of its two news editors, Patrick White, has recently been appointed as Canoë's editor (LAPLANTE, 2010). Patrick White26 is well known in Quebec as a cultural journalist and particularly, as the host of the blog PatWhite.com.

The QMI agency is a central hub of the convergence strategy. By aggregating journalistic productions from different sources (which all belong to the company) and structuring them in the same space, Québecor goes one step further in its strategy for the forced cooperation of all its outlets. Gains from the operation seem significant, since management is already showing its willingness to redistribute resources:



Finally, on the 16th of January 2010, and without much fanfare, a website specifically designed for Le Journal de Montréal appeared on the Canoë portal (journaldemontreal.canoe.ca). Until then, Québecor had systematically refused to build a separate site for the daily. 28 The online site was one of the paper's "demands" at the beginning of the lockout, a proposal to which the union had always publically agreed. The site took the form of a simple online adaptation of the paper. However, it is presented in Canoë's usual graphic layout.29

In summary, the Québecor conglomerate's move towards multiplatform production has been adopted on all fronts. The group launched an online broadcasting portal, Sun.tv, with the aim of occupying a dominant position with regard to future wireless platforms (CRTC, 2010). Québecor also announced "the development of 'Convergence 2.0,' an initiative that is expected to provide customers with solutions to market 
their products that combine all media platforms, including newspapers, the internet, television and possibly, in 2010, wireless telephony" (CRTC, 2010).

Indeed, as early as 2007, Québecor announced that it was hoping for a "third generation (3G)" wireless network, a high speed equivalent to existing cable internet connections. In 2008, the group obtained a license to develop its own network and compete with market leader Rogers (37\% of the Canadian market) and other important players like Bell. Québecor has already invested nearly one billion dollars in this endeavor (LA PRESSE, 2010). Its need for content, already digitized and organized by multitasking journalists, can only rapidly increase. "This new technology, which truly marks the crossroads of convergence, is fully aligned with Québecor Media's growth strategy," Péladeau explained during a speech at Ottawa's Cercle canadien. He continued: "within the Québecor family, we have almost all the elements of the production and distribution of content, from television to the internet, from music to film, which will allow us to provide our customers with a range of products designed and developed internally." (BELLEROSE, 2007-b). Almost everything...

\section{NOTES}

1 The definition borrowed here is that established by the members of a general program of research on media convergence, who proposed investigating "multi-platform" production, defined as "attempts to relate polymorphic productions, processed by a team of workers with low specialized status and expertise, using limited distribution media, inside groups of growing diversification." (GESTIN et al, 2009). However, to problematize the perspective on the Quebecois conglomerate, this study draws on the research of Domingo et al (2007), which addresses the polymorphism of media practices (e.g., journalists produce content for multiple media), the polymorphism of thematic practices (e.g., journalists handle information for different thematic sections), the polymorphism of technical practices (e.g., journalists are responsible for the majority of production). In addition, there is the polymorphism of the materiality of diffusion (e.g., media enterprises aggregate a set of increasingly heterogeneous platforms to distribute more or less the same information, at times tailoring it somewhat).

2 Le Cam, Florence (2005), L'identité du groupe des journalistes du Québec au défi d'Internet, Quebec-Rennes, Ph.D. dissertation, Université Laval/Université de Rennes 1, 555 pages.

3 We wish to thank Audrey Colle and Jean-Sébastien Barbeau, Masters degree students in Public Communication at Laval University, for their 
valuable assistance and Sarah-Louise Raillard (Raillard Translations, LLC), for the translation.

4 Guay, Jacques (1980). "Le Journal par lui-même." In: Florian Sauvageau, Gilles Lesage et Jean de Bonville, dans les coulisses de l'information Les journalistes, Montreal: Québec/Amérique, p. 99-126.

5 North American trade unionism is linked to local business and the specialized workforce that the union brings together. Every collective bargaining process takes place during a period set by law. During this period, the union has the right to implement pressure tactics, including strikes. However, the media owner also has the right to lay off union members and continue to produce, if possible, with other staff. This is called a "lockout."

6 Cross-media ownership refers to the integration by the same company of the content and form and to the convergence of new technologies, telecommunications and media (CEM, 2001). This refers specifically to the property, on the same market, of print and electronic media.

7 Netgraphe was one of the most important Francophone internet editing companies in Canada. Their operations were merged together with those of the portal Canoe.ca when Quebecor bought Netgraphe. The name Netgraphe was dropped in 2005. For information on the subject, see: DEMERS, François, Dommage collatéral de la globalisation financière - La chute de Conrad Black, le magnat de la presse de l'Anglosphère. Annuaire français de relations internationales (AFRI), Bruxelles, Bruylant, vol. X, 2009, p. 1049-1061.

8 Financial information site: argent.canoe.ca/

9 Job vacancies site: www.jobboom.com/

10 Contacts site: www.reseaucontact.com/

11 Search engine for sites in Québec: www.toile.com/

12 Technology portal:

13 Musical reality show: www.staracademie.ca/

14 Reality show: occupationdouble.canoe.ca/

15 The observation on the location at TVA-LCN was conducted in October 2002.

16 The observation on the location at Netgraphe-Canoë was conducted in December 2002.

17 Then located at: http://www.tva.canoe.qc.ca 
18 "R-65" indicates the number of the qualitative interview conducted with respondents (see Le Cam, 2005).

19 The texts used are cited in the text and referenced in the bibliography.

20 The lockout lasted from January 24th 2009 to February 26 th 2010.

21 The lockout ended on February 26, 2011 as a loss on all fronts for union members, including a reduction of overall staff from 253 to about 62 , including only 24 journalists. See http://tvanouvelles.ca/Icn/infos/ regional/archives/2011/02/20110226-124459.html. A few weeks later, the successful information site of the locked-out workers, RueFrontenac. com, was closed.

22 "With RueFrontenac.com, the locked-out workers of the Journal have not only the means to exert pressure, but they are also taking the opportunity to experience something of the new journalism." (DAUDENS, 2008).

23 http://journaldujournal.ca/dev2/index.php?option=com_content\&view $=$ article\&id=331\&ltemid $=100009$.

24 See the documentary Journal de Québec, history of a conflict, produced by the Canadian Union of Public Employees (CUPE). See: http://scfp.ca/ greves/media-matin-video.

25 See: http://www.canoe.com/cgi-bin/imprimer.cgi?id=787700.

26 Finally, in late 2011 , he was hired to become the editor of Huffington Post Quebec.

27 On the page L'heure juste, hosted on the site of Le Journal de Montréal: http://www. Iheurejuste.ca/Capsule.aspx? NavID=83\&CultureCode=frCA.

28 http://www.ledevoir.com/societe/medias/281241/medias-Québecormet-en-ligne-le-journal-de-montreal, by Fabien Deglise, accessed 201001-25.

29 In early February 2012, the websites of Le Journal de Québec and Le Journal de Montréal were considerably upgraded to new interactive versions. See: http://projetj.ca/article/virage-numerique-au-journal-demontreal. 


\section{IREFERENCES}

\section{Academic}

DE BONVILLE, Jean. La Presse québécoise de 1884 à 1914: genèse d'un média de masse. Quebec, Presses de I'Université Laval, 1988.

DEMERS, François. La chute de Conrad Black, le magnat de la presse de l'anglosphère. Dommage collatéral de la globalisation financière. Annuaire français de relations internationales (AFRI), vol. X, 2009, p. 1049-1061.

DEMERS, François. Concentration de la propriété des médias et réaménagement de la place publique médiatique ; leçons des affaires Voilà et Star Académie. Les Cahiers du Journalisme, no. 16, special issue: Médias généralistes et idéal journalistique: la fin d'une époque, Outono, 2006, p. 46-69.

DEMERS, François. La convergence comme nouvelle pratique journalistique. In: BERNIER, M. F.; DEMERS, F.; LAVIGNE, A. ; MOUMOUNI, C. ; WATINE, T. (orgs.). Pratiques novatrices en communication publique. Journalisme, relations publiques et publicité. Quebec, Les Presses de I'Université Laval, 2005, p. 77-101.

DEMERS, François Journalistes au Canada et au Quebec:

reconfiguration générale. Hermès, no. 35, 2003, p. 165-173.

DEMERS, François. Concentration des entreprises de presse : vers une reconfiguration du paysage médiatique au Quebec et au Canada. Les Cahiers du Journalisme, no. 8, 2000 p. 192-203.

DOMINGO, D. et al. Four dimensions of Journalistic Convergence: A Preliminary approach to current media trends in Spain. VIII INTERNATIONAL SYMPOSIUM OF ONLINE JOURNALISM. UNIVERSITY OF TEXAS AT AUSTIN. Austin, 30 de março de 2007. Anais..., 2007. Available at: < http://dutopianet.blogspot.com/2006/09/i-havespecialized-in-researching.html>. Accessed on: 03 mar. 2008.

GESTIN, Philippe, et al. La production multisupports dans des groupes médiatiques français. Les Cahiers du journalisme, no. 20, outono, 2009, p.84-95.

GUAY, Jacques. "Le Journal par lui-même." In: SAUVAGEAU, F. ; LESAGE, G. ; DE BONVILLE, J. (orgs.). Dans les coulisses de l'information Les journalistes. Montreal: Quebec/Amérique, 1980, p. 99-126.

LE CAM, Florence. Le journalisme imaginé. Histoire d'un projet professionnel au Quebec. Montreal: Lémeac, 2009. 
LE CAM, Florence; DEMERS, François. The Fundamental Role Played by Unionism in the Self-Structuration of The Group of Professional Journalists from Quebec. Canadian Journal of Communication, special issue on the Laboring of Communication, vol. 31 , outubro 2006, p. 659-674.

LE CAM, Florence. L'identité du groupe des journalistes du Quebec au défi d'Internet. 2005. 1.555 f. Tese (Doutorado em Comunicação. Université Laval (Canadá), Université de Rennes 1 (França), 2005.

LE CAM, Florence ; DEMERS, François. L'identité professionnelle des journalistes québécois. Petite histoire d'un événement-repère. COLLOQUE IDENTITE(S). Maison des Sciences de I'Homme et de la Société, Poitiers, 23 a 25 de janeiro de 2002. Atas... Presses de la MSHS de Poitiers, 2003, p. 157-170.

LE CAM, Florence. Internet in fabula : pratiques et représentations du journalisme en ligne dans la région de Quebec. In: DAMIAN, B.; RINGOOT, R.; THIERRY, D.; RUELLAN, D (ORGS.). Inform@tion.local: le paysage médiatique à l'ère électronique. Paris: L'Harmattan, 2001, p. 173-186.

QUINN, S.. An Intersection of Ideals: Journalism, Profits, Technology and Convergence, Convergence: the international Journal of research into new media technologies, vol. 10, dezembro de 2004, p. 109 123.

\section{Professional Literature}

BAILLARGEON, S., L'enlisement Le lock-out au Journal de Montréal aura un an dimanche. Le Devoir, 21 jan. 2010 , p. B8.

BELLEROSE, P. Canoë - Journaliste à tout faire. Le 30, jun. 2007a.

BELLEROSE, P. Le rebelle. Infopresse, jun. 2007b, p.32-33.

BLAIS, A. Patrick White se joint à QMI: "Mon objectif, c'est de bâtir la meilleure agence de presse possible". Le 30, 27 nov. 2009.

CAUCHON, P.. Une agence de presse interne pour Québecor Les textes des filiales du groupe alimenteront les pages du Journal de Montréal. Le Devoir, 29 jan. 2009 a.

CAUCHON, P.. Une agence de presse interne pour Québecor. Les textes des filiales alimenteront les pages du Journal de Montréal. Le Devoir, 24 jan. 2009b.

CRTC. Naviguer dans les eaux de la convergence : tableau des changements au sein de l'industrie des communications canadiennes 
et des répercussions sur la réglementation. Relatório, fev. 2010, DAUDENS, F.. Moyen de pression 2.0. Le 30, abr. 2009.

FORTIN, K.. Journal de Quebec - Un combat d'arrière-garde?. Le 30, vol. 31, n. 6, jun. 2007.

GIRARD, M. Netgraphe : non à I'OPA de Québecor. La Presse, La Presse Affaires 9, 12 jun. 2004.

LAPLANTE, R.. Branle-bas de combat chez QMI. Le 30, Vol. 34, n. 3, mar. 2012, p. 11.

LA PRESSE. Nouvelles installations de téléphonie sans fil de Vidéotron L'investissement frisera le milliard. La Presse Affaires, 12 jan. 2010, p. 4.

LE DEVOIR. Tension au JdeM. Les salariés de Québecor dénoncent l'entreprise, 5 out. 2001 , p. B8.

MARSAN, J.-S.. Netgraphe. 1996-2001. Vie et mort d'un coup de vent. Chronique netgraphienne, arquivado no site Sciencepresse, 2001. Available at: < http://www.sciencepresse.qc.ca/trucs/ netgraphe1.html >. Accessed on: 18 jun. 2004.

PELCHAT, P.. Règlement au Journal de Quebec. Les employés acceptent dans un fort pourcentage l'offre patronale. Le Soleil, 07 mar. 2008, p. 26.

PORTER, I.. Entente au Journal de Quebec. Des formations au «multiplateforme» pour le retour des employés. Le Devoir, 05 ago. 2008 p. B8.

PROULX, M.-H.. L'information en transformation - Le blues du multitâche. Le 30, abr. 2008.

SHIELDS, A.. Assemblée annuelle des actionnaires Québecor presse le virage médiatique. Le Devoir, ÉCONOMIE, 14 mai. 2009 (2009-0514), p. B1.

TRUDEL, J.. La bataille des portails. Les Bell, Québecor et Vidéotron se livrent une lutte sans merci pour attirer les internautes vers leurs portails, ces portes d'entrée dans le cyberespace. L'Actualité, vol. 25, n. 14,15 Set. 2000 , p. 56.

YAKABUSHI, C.. A beautiful machine. With the help of his star soul mate, Julie Snyder, Québecor CEO Pierre Karl Péladeau has done the unthinkable: He's made convergence work. The Globe and Mail, Report on Business, set. 2003, p. 50-59.

RECEVEID ON: 30/03/2012 | APPROVED ON: 28/11/2012 
MULTI-PLATFORM PRODUCTION

BRAZILIAN JOURNALISM RESEARCH-Volume 8- Número z- zoIa| 249 